\title{
PENURUNAN TSS, BOD DAN COD LIMBAH CAIR INDUSTRI TAHU DI DESA CILONGOK KABUPATEN BANYUMAS MENGGUNAKAN SISTEM ZEOLIT TERAKTIVASI DAN TERIMPREGNASI $\mathrm{TiO}_{2}$
}

\author{
Suyata, Irmanto \\ Program Studi Kimia, Jurusan MIPA \\ Fakultas Sains dan Teknik, Universitas Jenderal Soedirman, Purwokerto
}

\begin{abstract}
Activated and impregnated $\mathrm{TiO}_{2}$ zeolite systems to reduce TSS, BOD, and COD of tofu industrial wastewater in Cilongok Villages had been developed. Activated and impregnated zeolite systems were expected to be able to reduce the concentration of TSS, BOD, and COD. Thus, the research was aimed to know the ability of zeolite systems to reduce the concentration of TSS, BOD, and COD of tofu industrial wastewater. The research used five difference loading rates of tofu industrial wastewater which were 160, 240, 320, 400, and $480 \mathrm{~L} \mathrm{~m}^{-2}$ day $^{-1}$. The most effective loading rate was determined by analyzing the concentration of TSS, BOD, and COD before and after processing using zeolite systems. The reduced concentration of TSS, BOD, and COD was determined by filling the activated and impregnated zeolite with industrial wastewater for 24 hours continuously in 30 days. Sampling was done in every 5 days with loading rate of $320 \mathrm{~L} \mathrm{~m}^{-2}$ day $^{-1}$. The results indicated that zeolite systems could reduce the concentration of TSS, $\mathrm{BOD}$, and COD of tofu industrial wastewater. The optimum loading rate to reduce the concentration of TSS, BOD, and COD was $320 \mathrm{~L} \mathrm{~m}^{-2}$ day ${ }^{-1}$. The efficiency of acid activated zeolite system in reducing the concentration of TSS, BOD, and COD were $83.348 \%, 91.899 \%$, and $90.700 \%$, respectively. The efficiency of base activated zeolite system in reducing the concentration of TSS, BOD, and COD were $84.380 \%, 93.711 \%$, and $91.928 \%$, respectively. The efficiency of impregnated zeolite system in reducing the concentration of TSS, BOD, and COD were 82.410\%, 90.711\%, and $89.917 \%$, respectively.
\end{abstract}

Keywords : TSS, BOD, COD, tofu industrial wastewater.

\section{PENDAHULUAN}

Limbah cair industri tahu memiliki kadar bahan organik serta kekeruhan yang tinggi dengan $\mathrm{pH}$ yang rendah. Limbah cair ini masih banyak mengandung protein, karena pada proses pembuatan tahu tidak semua protein yang terdapat dalam kacang kedelai dapat diekstrak. Protein yang tidak digumpalkan tersebut terbuang dalam limbah (Yusman, 1987 dalam Majiburrohman, 2000). Limbah cair industri tahu yang dihasilkan cukup besar yaitu $15-20 \mathrm{~m}^{3}$ air limbah per ton kedelai yang diolah (Nurhasan dan Pramudyanto, 1991).

Tingginya kadar TSS, BOD dan COD limbah cair industri tahu yaitu sebesar 638-660 mg/l, 6000-8000 mg/l, dan 7500-14000 $\mathrm{mg} / \mathrm{l}$ dapat menyebabkan kematian bagi biota perairan akibat kekurangan oksigen (Nurhasan dan Pramudyanto, 1997). Limbah cair industri tahu yang langsung dibuang ke badan perairan dapat mencemari badan perairan dan terganggunya ekosistem biota perairan sehingga menurunkan kualitas lingkungan. Harian Radar Banyumas 
edisi 6 September 2005 melaporkan bahwa limbah cair industri tahu di desa Kalisari Kabupaten Banyumas telah mencemari hampir seluruh aliran air seperti sungai, selokan bahkan di beberapa lahan tanah. Dampaknya banyak timbul masalah lingkungan seperti bau menyengat, pencemaran air dan kontaminasi air limbah pada daerah resapan air yang disebabkan oleh pembuangannya langsung ke aliran sungai.

Berdasarkan penelitian yang dilakukan Poerwadi dkk., (1998) zeolit alam asal Turen yang telah diaktivasi dengan asam klorida $(\mathrm{HCl})$ ternyata dapat menurunkan kandungan logam $\mathrm{Pb}, \mathrm{Zn}$ dan $\mathrm{Cu}$ dalam limbah cair sampai dengan $30 \%$, sedangkan kandungan amonium, sulfat dan nitrat dapat diturunkan sampai dengan $35 \%$. Zeolit mempunyai sifat amfoter yang berarti zeolit bisa diaktifkan dengan basa atau asam. Oleh sebab itu perlu dilakukan penelitian menggunakan sistem zeolit yang diaktivasi dengan asam, basa, dan zeolit terimpregnasi sehingga dapat diketahui sistem zeolit yang efektif dalam penurunan nilai TSS, BOD dan COD limbah cair industri tahu. Sistem zeolit juga diaerasi sehingga diharapkan proses yang terjadi tidak hanya adsorpsi tetapi juga proses dekomposisi pada limbah cair industri tahu.

\section{METODE PENELITIAN Alat dan Bahan}

Alat-alat yang digunakan dalam penelitian ini adalah instrumen sistem terdiri dari : kotak kaca dengan ukuran 30 x 15 x $30 \mathrm{~cm}$ (panjang x lebar x tinggi), zeolit yang berasal dari daerah Yogyakarta deposit Gunung Kidul (dengan ukuran 1-2 mm), pipa paralon, pipa aerasi, pompa air, penampung limbah, kran air, alat-alat gelas, termometer, $\mathrm{pH}$ meter, desikator, pompa udara (aerator), botol Winkler, buret dan statif, oven, penangas, alat pengaduk mekanis, kertas Whatman nomor 40.

Bahan-bahan yang digunakan dalam penelitian ini adalah limbah cair industri tahu, $\mathrm{MnSO}_{4}, \mathrm{KOH}, \mathrm{KI}, \mathrm{NaN}_{3}$, $\mathrm{Na}_{2} \mathrm{~S}_{2} \mathrm{O}_{3}, \mathrm{FeCl}_{3}, \mathrm{CaCl}_{2}, \mathrm{MgSO}_{4}, \mathrm{H}_{2} \mathrm{SO}_{4}$, $\mathrm{KMnO}_{4}, \mathrm{~K}_{2} \mathrm{Cr}_{2} \mathrm{O}_{7}, \mathrm{HCl}, \mathrm{KI}, \mathrm{H}_{2} \mathrm{SO}_{4}$ pekat, $\mathrm{HCl}, \mathrm{NaOH}, \mathrm{TiO}_{2}$, buffer fosfat, indikator amilum dan air suling.

\section{Prosedur Penelitian}

\section{Aktivasi dan Impregnasi zeolit \\ Aktivasi zeolit melalui pengasaman (Sugiyanto, 2006)}

Butiran zeolit direndam dengan akuades selama 24 jam pada suhu kamar, setelah itu disaring dan keringkan menggunakan oven pada suhu $110{ }^{\circ} \mathrm{C}$. Zeolit serbuk yang telah kering direndam dengan $\mathrm{HCl}$ 0,1 $\mathrm{M}$, disaring dan dicuci dengan akuades secara berulang-ulang dan dikeringkan dengan oven pada suhu $130{ }^{0} \mathrm{C}$.

\section{Aktivasi zeolit melalui pembasaan}

Butiran zeolit direndam dengan akuades selama 24 jam pada suhu kamar, setelah itu disaring dan keringkan menggunakan oven pada suhu $110{ }^{0} \mathrm{C}$. Zeolit serbuk yang telah kering direndam dengan $\mathrm{NaOH} 0,1 \mathrm{M}$, disaring dan dicuci dengan akuades secara berulang-ulang dan dikeringkan dengan oven pada suhu $130{ }^{0} \mathrm{C}$.

\section{Impregnasi zeolit dengan $\mathrm{TiO}_{2}$ (Sugiyanto, 2006)}

Butiran zeolit dicampur dengan $\mathrm{TiO}_{2}$ dengan perbandingan jumlah zeolit dan $\mathrm{TiO}_{2}$ 2,5:1. Campuran diaduk selama 3 jam. Setelah itu, ditambah dengan akuades kemudian dikalsinasi pada suhu $400{ }^{\circ} \mathrm{C}$.

\section{Pembuatan sistem zeolit}

Instrumen sistem zeolit dibuat dengan konstruksi sebagai berikut. Bak kaca berukuran dimensi $(30$ × 15 x 30 $\mathrm{cm}$ ) dengan kran alir pada bagian bawah 
disiapkan. Sistem zeolit terdiri dari tiga bak setiap bak masing-masing dari dasar sampai ke atas seluruhnya diisi dengan zeolit berdiameter 1-2 mm yang berbeda cara aktivasi dan modifikasinya yaitu melalui pengasaman, pembasaan dan impregnasi $\mathrm{TiO}_{2}$. Pada bagian tengah bak dipasang pipa aerasi dengan diameter 1,5 $\mathrm{cm}$ dengan jarak antar lubang aerasi $5 \mathrm{~cm}$ dan ukuran diameter lubang $0,5 \mathrm{~mm}$. Pipa aliran masuk berupa pipa berlubang yang dibuat dengan ukuran diameter 1,5 $\mathrm{mm}$ dan jarak antar lubang $5 \mathrm{~cm}$, bagian pipa yang berlubang menghadap ke atas dan diletakkan di atas sistem zeolit.

\section{Penentuan kecepatan pengisian optimum air limbah}

Penentuan $\mathrm{pH}$, nilai TSS, BOD, dan COD dalam limbah cair tahu sebelum diolah (treatment) menggunakan metode sistem zeolit. Pengukuran ini dilakukan secara duplo untuk setiap parameter. Selanjutnya limbah cair industri tahu dialirkan ke dalam sistem selama 24 jam per hari pada berbagai variasi kecepatan pengisian yaitu 160 , 240, 320, 400, $480 \quad 1 \mathrm{~m}^{-2}$ hari $^{-1}$. Kemudian nilai TSS, BOD dan COD limbah cair industri tahu dianaliasis pada berbagai variasi kecepatan pengisian setelah diolah dengan metode sistem zeolit. Sampling dilakukan dua hari sekali dengan masing-masing parameter dianalisis secara duplo.

Penentuan nilai TSS, BOD dan COD limbah cair industri tahu sebelum dan setelah diperlakukan dengan sistem zeolit

(1) Masing-masing parameter dianalisis sesuai dengan metode analisis

(2) Pengukuran dilakukan secara duplo

Penentuan persentase penurunan kadar masing-masing parameter

$\%$ penurunan $=\frac{(C o-C 1)}{C o} \times 100 \%$

Dimana:
Co $=$ konsentrasi awal parameter

$\mathrm{C} 1=$ konsentrasi akhir parameter

HASIL DAN PEMBAHASAN

Penentuan Kecepatan Pengisian

Optimum Limbah Cair Industri Tahu Pada Sistem Zeolit

Penentuan kecepatan pengisian limbah ke dalam sistem zeolit menjadi faktor yang berpengaruh terhadap penurunan bahan-bahan organik. Kecepatan pengisian yang optimum memberikan waktu kontak kepada sistem untuk mengadsorpsi komponen limbah secara maksimal, selain itu memberikan kesempatan bakteri atau mikroorganisme untuk berkembang. Aliran limbah cair yang masuk ke dalam sistem zeolit pun haruslah merata, sehingga limbah dapat terdistribusi secara sempurna. Sebelum digunakan untuk menentukan kecepatan pengisian optimum, sistem zeolit dikondisikan selama 14 hari. Limbah cair industri tahu yang masuk ke dalam sistem diencerkan terlebih dahulu sebanyak 10 kali yaitu 1 liter limbah cair tahu dicampur dengan 9 liter air. Pengkondisian sistem zeolit bertujuan agar mikroorganisme dapat berkembang dan beradaptasi serta dapat mendekomposisi limbah cair industri tahu. Pengenceran dilakukan karena limbah cair industri tahu memiliki karbohidrat $(0,51 \%)$ dan protein $(0,08 \%)$ yang tinggi sehingga limbah cair industri tahu cepat menggumpal jika berada di udara terbuka (Nurhasan dan Pramudyanto, 1997). Diharapkan dengan pengenceran, limbah cair industri tahu dapat terdistribusi secara merata ke dalam sistem tanpa terjadi penggumpalan.

Limbah cair industri tahu dialirkan dengan kecepatan pengisian berturut-turut 160, 240, 320, 400, 4801 $\mathrm{m}^{-2}$ hari ${ }^{-1}$. Variasi kecepatan pengisian bertujuan untuk memperoleh kecepatan pengisian yang optimum bagi sistem zeolit. Kecepatan pengisian ini diujikan kepada setiap sistem zeolit dan dilakukan 
analisis setiap 2 hari sekali untuk satu kecepatan pengisian. Analisis dilakukan pada setiap parameter yaitu nilai TSS, BOD dan COD sebelum dan sesudah diolah menggunakan sistem zeolit. Hasil analisis limbah cair industri tahu sebelum dan sesudah diolah dengan ketiga sistem zeolit pada berbagai kecepatan pengisian dapat dilihat pada Gambar 1, 2 dan 3.

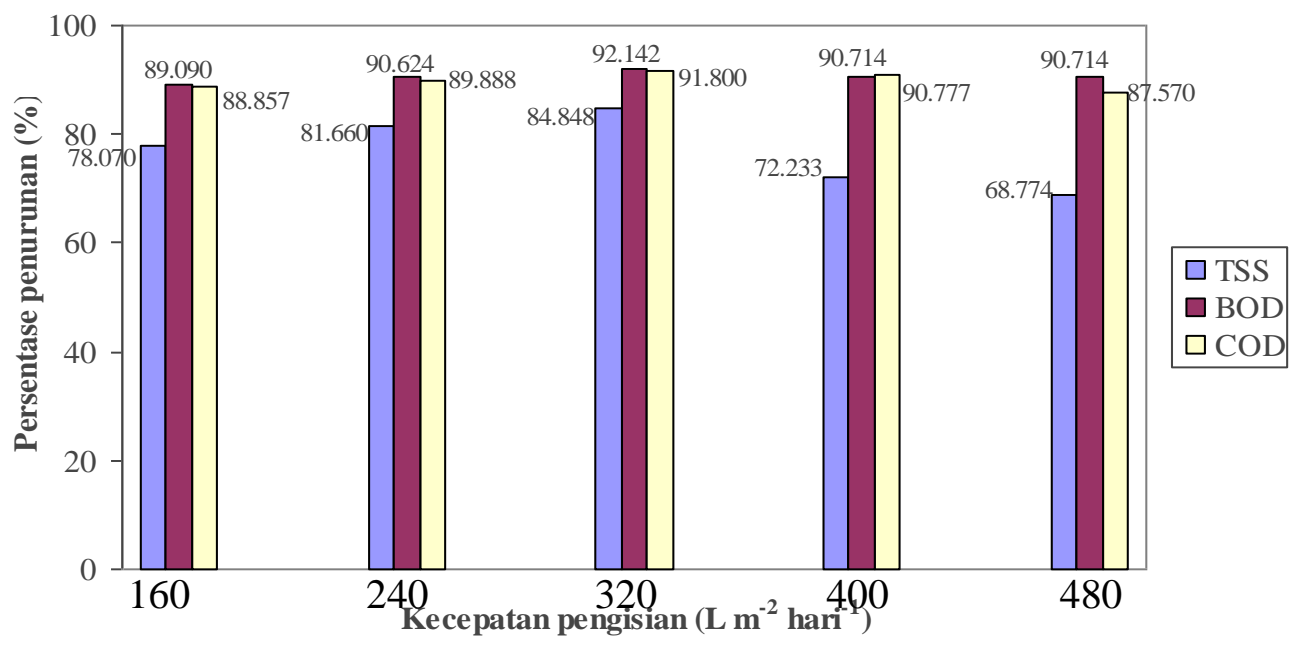

Gambar 1. Kurva persentase penurunan nilai TSS, BOD dan COD limbah cair industri tahu pada berbagai variasi kecepatan pengisian sistem zeolit teraktivasi asam

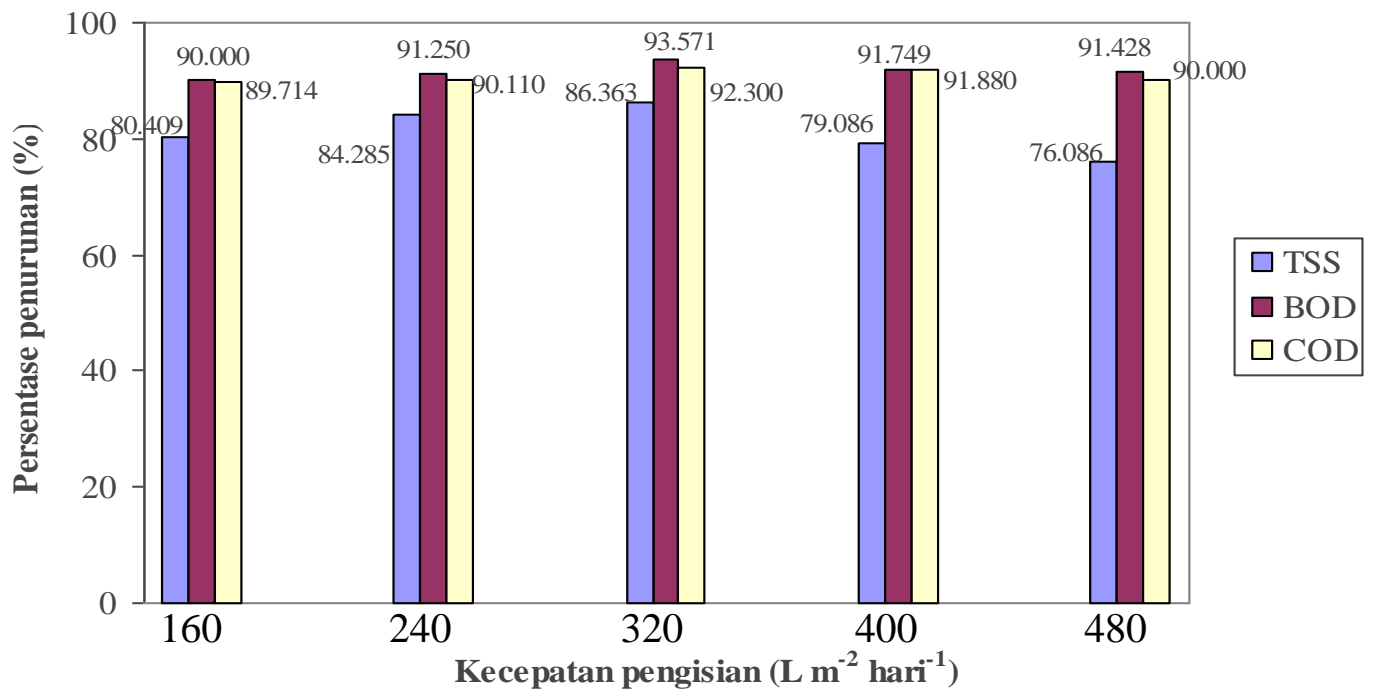

Gambar 2. Kurva persentase penurunan nilai TSS, BOD dan COD limbah cair industri tahu pada berbagai variasi kecepatan pengisian sistem zeolit teraktivasi basa

Persentase penurunan terbesar dari ketiga sistem zeolit untuk tiga parameter yaitu TSS, BOD dan COD terjadi pada kecepatan pengisian $320 \mathrm{~L}$ $\mathrm{m}^{-2}$ hari $^{-1}$ seperti terlihat pada Gambar 1 , 2 dan 3. Sistem zeolit teraktivasi asam dapat menurunkan nilai TSS, BOD dan COD berturut-turut sebesar $84,848 \%$;
92,142 \%; dan 91,800\%. Sedangkan untuk sistem zeolit teraktivasi basa penurunan TSS, BOD dan COD berturutturut sebesar $86,363 \%$; 93,571 \%; dan $92,300 \%$ dan penurunan TSS, BOD dan COD pada sistem terimpregnasi berturutturut sebesar 84,843\%; 91,428\%; dan $90,80 \%$. 


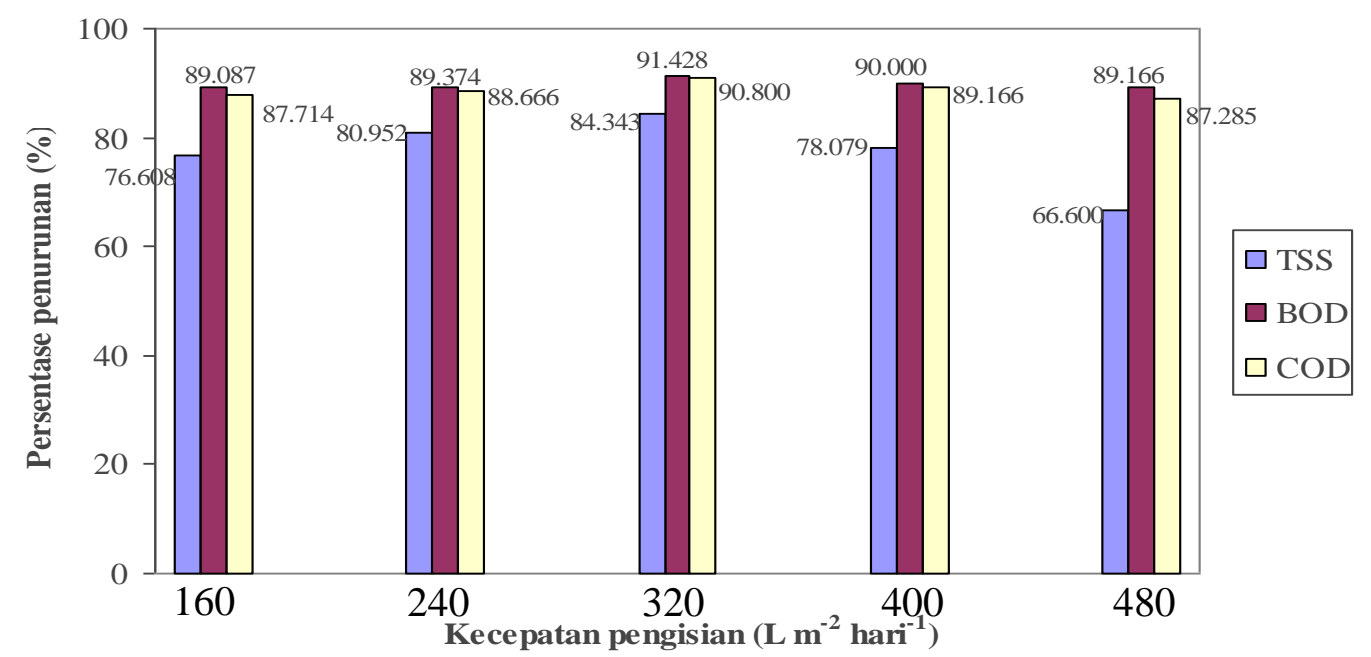

Gambar 3. Kurva persentase penurunan nilai TSS, BOD dan COD limbah cair industri tahu pada berbagai variasi kecepatan pengisian sistem zeolit terimpregnasi $\mathrm{TiO}_{2}$

Persentase penurunan TSS, BOD dan COD limbah cair industri tahu sistem teraktivasi asam mengalami kenaikan dari kecepatan pengisian $160 \mathrm{l} \mathrm{m}^{-2}$ hari $^{-1}$ sampai kecepatan $320 \quad 1 \quad \mathrm{~m}^{-2}$ hari $^{-1}$. Selanjutnya akan mengalami penurunan setelah kecepatan $3201 \mathrm{~m}^{-2}$ hari $^{-1}$ yaitu kecepatan 400 dan $480 \quad 1 \mathrm{~m}^{-2}$ hari $^{-1}$. Sistem zeolit teraktivasi basa dan terimpregnasi $\mathrm{TiO}_{2}$ juga menunjukkan gejala yang sama. Lebih rendahnya penurunan tiga parameter yaitu TSS, BOD dan COD untuk ketiga sistem pada kecepatan pengisian dibawah $3201 \mathrm{~m}^{-2}$ hari $^{-1}$ disebabkan dekomposisi limbah tidak berlangsung secara maksimal. Sedangkan rendahnya penurunan pada kecepatan 400 dan $480 \quad 1 \quad \mathrm{~m}^{-2}$ hari $^{-1}$ dibandingkan pada kecepatan $320 \mathrm{l} \mathrm{m}^{-2}$ hari $^{-1}$ disebabkan mikroorganisme dalam sistem zeolit yang berfungsi untuk merombak atau mendekomposisi limbah tidak berada dalam kondisi optimal karena aliran limbah yang masuk ke dalam sistem zeolit terlalu cepat. Keadaan ini juga akan menyebabkan proses adsorpsi limbah oleh zeolit dan dekomposisi limbah oleh mikroorganisme berlangsung tidak sempurna.

Efisiensi Sistem Zeolit Dalam Menurunkan Nilai TSS, BOD dan COD Limbah Cair Industri Tahu

Penentuan efisiensi sistem zeolit teraktivasi dan terimpregnasi $\mathrm{TiO}_{2}$ dilakukan pada kecepatan pengisian optimum yaitu $3201 \mathrm{~m}^{-2}$ hari $^{-1}$. Sebelum digunakan untuk menentukan efisiensi sistem zeolit, sistem dikondisikan selama 1 minggu. Hal ini bertujuan untuk membentuk kondisi yang optimal dalam sistem zeolit. Selain itu proses perombakan secara bakterial diawali dengan memecah limbah organik mencapai ukuran yang lebih kecil sampai memungkinkan bagi organisme untuk melakukan metabolisme dan proses ini diperlukan waktu adaptasi (Pike, 1975 dalam Suwarso, 2004). Pengkondisian sistem selain untuk membentuk kondisi yang optimal juga bertujuan untuk memberikan waktu pada bakteri atau mikroorganisme untuk beradaptasi dengan limbah. Analisis limbah dilakukan sebanyak 6 kali tiap 5 hari selama 30 hari untuk mengetahui kemampuan ketiga sistem zeolit dalam 
menurunkan nilai TSS, BOD dan COD limbah cair industri tahu.

Efisiensi sistem zeolit adalah hasil rata-rata persentase penurunan tiap parameter pada masing-masing sistem zeolit selama waktu pengisian optimum. Hasil pengukuran efisiensi sistem zeolit dalam menurunkan nilai TSS, BOD dan COD limbah cair industri tahu sebagai berikut :

\section{Total Suspended Solid (TSS)}

Hasil pengukuran TSS pada kecepatan pengisian optimum menunjukkan persentase yang tidak jauh berbeda pada ketiga sistem zeolit. Penurunan nilai TSS pada kecepatan pengisian $320 \mathrm{l} \mathrm{m}^{-2}$ hari $^{-1}$ untuk ketiga sistem ditunjukkan pada Tabel 1, 2 dan 3.

Tabel 1. Efisiensi sistem zeolit teraktivasi asam dalam menurunkan nilai TSS limbah cair industri tahu

\begin{tabular}{|c|c|c|c|c|}
\hline \multirow{2}{*}{$\begin{array}{c}\text { Waktu } \\
\text { sampling }\end{array}$} & \multicolumn{2}{|c|}{ Nilai TSS (mg/l) } & \multirow{2}{*}{$\begin{array}{c}\text { Persentase } \\
\text { Penurunan } \\
\quad(\%)\end{array}$} & \multirow[t]{2}{*}{ Efisiensi (\%) } \\
\hline & $\begin{array}{c}\text { Sebelum } \\
\text { diolah }\end{array}$ & $\begin{array}{c}\text { Sesudah } \\
\text { diolah }\end{array}$ & & \\
\hline Hari ke-5 & 175 & 27 & 84,500 & \\
\hline Hari ke-10 & 215 & 35 & 83,720 & \\
\hline Hari ke-15 & 206 & 37 & 82,038 & 83,348 \\
\hline Hari ke-20 & 200 & 31 & 84,500 & \\
\hline Hari ke-25 & 190 & 30 & 84,210 & \\
\hline Hari ke-30 & 196 & 37 & 81,122 & \\
\hline
\end{tabular}

Tabel 2. Efisiensi sistem zeolit teraktivasi basa dalam menurunkan nilai TSS limbah cair industri tahu

\begin{tabular}{|c|c|c|c|c|}
\hline \multirow{2}{*}{$\begin{array}{c}\text { Waktu } \\
\text { sampling }\end{array}$} & \multicolumn{2}{|c|}{ Nilai TSS (mg/l) } & \multirow{2}{*}{$\begin{array}{c}\text { Persentase } \\
\text { Penurunan } \\
(\%)\end{array}$} & \multirow[t]{2}{*}{ Efisiensi (\%) } \\
\hline & $\begin{array}{c}\text { Sebelum } \\
\text { diolah }\end{array}$ & $\begin{array}{c}\text { Sesudah } \\
\text { diolah }\end{array}$ & & \\
\hline Hari ke-5 & 175 & 25 & 85,714 & \\
\hline Hari ke-10 & 215 & 32 & 85,116 & \\
\hline Hari ke-15 & 206 & 34 & 83,495 & 84,380 \\
\hline Hari ke-20 & 200 & 33 & 83,500 & \\
\hline Hari ke-25 & 190 & 26 & 86,315 & \\
\hline Hari ke-30 & 196 & 35 & 82,142 & \\
\hline
\end{tabular}

Tabel 3. Efisiensi sistem zeolit terimpregnasi $\mathrm{TiO}_{2}$ dalam menurunkan nilai TSS limbah cair industri tahu

\begin{tabular}{ccccc}
\hline Waktu & \multicolumn{2}{c}{ Nilai TSS (mg/l) } & \multirow{2}{\text{Persentase}}{} & Efisiensi (\%) \\
\cline { 2 - 3 } sampling & $\begin{array}{c}\text { Sebelum } \\
\text { diolah }\end{array}$ & $\begin{array}{c}\text { Sesudah } \\
\text { diolah }\end{array}$ & $\begin{array}{c}\text { Penurunan } \\
(\%)\end{array}$ & \\
\hline Hari ke-5 & 175 & 30 & 82,857 & \\
Hari ke-10 & 215 & 34 & 84,186 & 82,415 \\
Hari ke-15 & 206 & 39 & 81,067 & \\
Hari ke-20 & 200 & 38 & 81,000 & \\
Hari ke-25 & 190 & 27 & 85,789 & \\
Hari ke-30 & 196 & 40 & 79,591 & \\
\hline
\end{tabular}


Nilai TSS setelah pengolahan menggunakan sistem zeolit berkisar antara $25-40 \mathrm{mg} / \mathrm{l}$ yang telah memenuhi standar baku mutu yang ditetapkan yaitu $100 \mathrm{mg} / \mathrm{l}$. Nilai efisiensi masing-masing sistem dalam menurunkan TSS tidak jauh berbeda. Efisiensi sistem zeolit dalam menurunkan nilai TSS cukup besar yaitu $83,348 \%$ untuk sistem zeolit teraktivasi asam, 84,380 \% untuk sistem zeolit teraktivasi basa, dan $82,415 \%$ untuk sistem zeolit terimpregnasi $\mathrm{TiO}_{2}$. Penurunan yang cukup besar ini dikarenakan zeolit mempunyai sifat penukar kation dan mampu menyerap TSS dalam sistem pengolahan limbah. Berdasarkan sifat tersebut maka zeolit dapat digunakan sebagai penyerap bau (Torri, 1978 dalam Purwati, 1997). Selain itu tingginya penurunan TSS disebabkan oleh adanya degradasi limbah oleh mikroorganisme pada sistem zeolit. Pada kecepatan pengisian optimum mikroorganisme bekerja merombak secara maksimal sehingga menghasilkan persentase penurunan yang besar.

\section{Biochemical Oxygen Demand (BOD)}

Pengukuran nilai BOD pada penentuan efisiensi dilakukan pada kecepatan $3201 \mathrm{~m}^{-2}$ hari $^{-1}$. Nilai BOD merupakan gambaran mengenai banyaknya jumlah oksigen yang dibutuhkan bagi stabilitas bahan-bahan organik oleh aktivitas mikroorganisme aerob. Proses stabilisasi secara aerob akan mengakibatkan sel-sel mikroorganisme mengkonsumsi protoplasmanya sendiri sedangkan jaringan sel teroksidasi menjadi karbon dioksida, air dan amonia dan hanya sekitar 20-25\% bahan organik yang tidak terurai secara biologis (Santoso dan Gading, 1994). Penurunan nilai BOD limbah cair industri tahu dengan kecepatan pengisian optimum pada ketiga sistem zeolit dapat ditunjukkan pada Tabel 4, 5 dan 6.

Tabel 4. Efisiensi sistem zeolit teraktivasi asam dalam menurunkan nilai BOD limbah cair industri tahu

\begin{tabular}{|c|c|c|c|c|}
\hline \multirow{2}{*}{$\begin{array}{c}\text { Waktu } \\
\text { sampling }\end{array}$} & \multicolumn{2}{|c|}{ Nilai BOD (mg/l) } & \multirow{2}{*}{$\begin{array}{c}\text { Persentase } \\
\text { Penurunan } \\
\quad(\%)\end{array}$} & \multirow[t]{2}{*}{ Efisiensi (\%) } \\
\hline & $\begin{array}{c}\text { Sebelum } \\
\text { diolah }\end{array}$ & $\begin{array}{c}\text { Sesudah } \\
\text { diolah }\end{array}$ & & \\
\hline Hari ke-5 & 1484,508 & 104,788 & 92,941 & \\
\hline Hari ke-10 & 960,563 & 69,858 & 92,727 & \\
\hline Hari ke-15 & 956,689 & 78,275 & 91,818 & 91,899 \\
\hline Hari ke-20 & 1294,013 & 94,895 & 92,666 & \\
\hline Hari ke-25 & 894,190 & 78,273 & 91,246 & \\
\hline Hari ke-30 & 1466,549 & 146,655 & 89,999 & \\
\hline
\end{tabular}

Tabel 5. Efisiensi sistem zeolit teraktivasi basa dalam menurunkan nilai BOD limbah cair industri tahu

\begin{tabular}{|c|c|c|c|c|}
\hline \multirow{2}{*}{$\begin{array}{c}\text { Waktu } \\
\text { sampling }\end{array}$} & \multicolumn{2}{|c|}{ Nilai BOD (mg/l) } & \multirow{2}{*}{$\begin{array}{c}\text { Persentase } \\
\text { Penurunan } \\
\quad(\%)\end{array}$} & \multirow[t]{2}{*}{ Efisiensi (\%) } \\
\hline & $\begin{array}{c}\text { Sebelum } \\
\text { diolah }\end{array}$ & $\begin{array}{c}\text { Sesudah } \\
\text { diolah }\end{array}$ & & \\
\hline Hari ke-5 & 1484,508 & 87,323 & 94,117 & \\
\hline Hari ke-10 & 960,563 & 61,125 & 93,636 & \\
\hline Hari ke-15 & 956,689 & 60,881 & 93,636 & 93,711 \\
\hline Hari ke-20 & 1294,013 & 60,387 & 95,333 & \\
\hline Hari ke-25 & 894,190 & 60,881 & 93,191 & \\
\hline Hari ke-30 & 1466,549 & 112,147 & 92,353 & \\
\hline
\end{tabular}


Tabel 6. Efisiensi sistem zeolit terimpregnasi $\mathrm{TiO}_{2}$ dalam menurunkan nilai BOD limbah cair industri tahu

\begin{tabular}{|c|c|c|c|c|}
\hline \multirow{2}{*}{$\begin{array}{c}\text { Waktu } \\
\text { sampling }\end{array}$} & \multicolumn{2}{|c|}{ Nilai BOD (mg/l) } & \multirow{2}{*}{$\begin{array}{c}\text { Persentase } \\
\text { Penurunan } \\
\quad(\%)\end{array}$} & \multirow[t]{2}{*}{ Efisiensi (\%) } \\
\hline & $\begin{array}{c}\text { Sebelum } \\
\text { diolah }\end{array}$ & $\begin{array}{c}\text { Sesudah } \\
\text { diolah }\end{array}$ & & \\
\hline Hari ke-5 & 1484,508 & 113,520 & 92,353 & \\
\hline Hari ke-10 & 960,563 & 87,398 & 90,901 & \\
\hline Hari ke-15 & 956,689 & 95,668 & 90,000 & 90,711 \\
\hline Hari ke-20 & 1294,013 & 112,148 & 91,333 & \\
\hline Hari ke-25 & 894,190 & 86,972 & 90,273 & \\
\hline Hari ke-30 & 1466,549 & 155,381 & 89,411 & \\
\hline
\end{tabular}

Setelah pengolahan menggunakan zeolit, sebagian besar nilai BOD yang berkisar 60-156 $\mathrm{mg} / \mathrm{l}$ telah memenuhi standar baku mutu $(150 \mathrm{mg} / \mathrm{l})$ yang ditetapkan. Sistem zeolit berfungsi dengan optimal dalam menyerap dan mendegradasi limbah cair industri tahu sehingga nilai BOD mengalami penurunan yang besar. Penurunan ini disebabkan karena zeolit mempunyai pori-pori yang lebih luas setelah diaktivasi dan dimodifikasi dan dapat menyerap limbah organik secara optimal. Proses tersebut berkaitan dengan terjadinya ikatan kimia antara gugus aktif pada bahan organik dengan padatan melalui interaksi asam-basa Lewis yang menghasilkan komplek pada permukaan padatan (Amun dkk, 2004). Interakasi ini terjadi karena pasangan elektron pada gugus aktif bahan organik menempati orbital $d$ kosong pada $\mathrm{Al}^{3+}$ dalam zeolit. Untuk sistem zeolit terimpregnasi $\mathrm{TiO}_{2}$, limbah organik juga dapat berinteraksi dengan $\mathrm{TiO}_{2}$ dengan cara yang sama yaitu pasangan elektron bebas pada limbah organik mengisi orbital $3 d$ yang belum penuh pada Ti.

Kation-kation dalam kerangka zeolit dapat ditukar dan disubsitusi tanpa merubah stuktur kerangka yang dapat menimbulkan gradien medan elektonik dalam kanal-kanal dan ruangan-ruangan zeolit. Gradien ini akan dialami oleh semua adsorbat yang masuk ke pori-pori zeolit, sehingga mengakibatkan kelakuan-kelakuan zat yang teradsorpsi seperti tingkat dissosiasi, konduktivitas dan lainnya dalam keadaan normal. Hal ini menyebabkan teradsorpsinya molekul polar maupun non polar ke dalam zeolit (Smith, 1992 dalam Setyawan dan Handoko, 2004).

Mikroorgansime mendekomposisi limbah cair industri tahu secara optimal. Untuk mendekomposisi limbah organik, mikroorganisme harus mempunyai oksigen yang cukup. Adanya aerasi pada sistem zeolit berfungsi untuk menyuplai oksigen yang dibutuhkan oleh mikroorganisme untuk mendekomposisi limbah secara optimal. Perombakan bahan organik secara bakterial dengan tersedianya cukup oksigen akan berlangsung proses dekomposisi secara aerobik yang pada umumnya tidak menghasilkan zat-zat toksik bagi organisme akuatik. Sebaliknya apabila tidak tersedia cukup oksigen maka akan berlangsung perombakan secara anaerobik dan dihasilkan $\mathrm{H}_{2} \mathrm{~S}$ dan amoniak yang bersifat toksik bagi organisme akuatik (Dahuri, 1984 dalam Widodo, 2005).

Proses perombakan secara bakterial diawali dengan memecah limbah organik mencapai ukuran yang lebih kecil sampai memungkinkan bagi organisme untuk melakukan metabolisme dan proses ini diperlukan waktu adaptasi sehubungan dengan karakteristik limbah 
tersebut (Pike, 1975 dalam Suwarso, 2004).

\section{Chemical Oxygen Demand (COD)}

Analisis COD limbah cair industri

tahu dilakukan pada kecepatan pengisian optimum yaitu $3201 \mathrm{~m}^{-2}$ hari $^{-1}$. Hasil pengukuran COD limbah cair industri tahu menggunakan ketiga sistem zeolit ditunjukkan pada Tabel 7, 8 dan 9 .

Tabel 7. Efisiensi sistem zeolit teraktivasi asam dalam menurunkan nilai COD limbah cair industri tahu

\begin{tabular}{|c|c|c|c|c|}
\hline \multirow{2}{*}{$\begin{array}{c}\text { Waktu } \\
\text { sampling }\end{array}$} & \multicolumn{2}{|c|}{ Nilai COD (mg/l) } & \multirow{2}{*}{$\begin{array}{c}\text { Persentase } \\
\text { Penurunan } \\
\quad(\%)\end{array}$} & \multirow[t]{2}{*}{ Efisiensi (\%) } \\
\hline & $\begin{array}{c}\text { Sebelum } \\
\text { diolah }\end{array}$ & $\begin{array}{c}\text { Sesudah } \\
\text { diolah }\end{array}$ & & \\
\hline Hari ke-5 & 1984,000 & 202,368 & 89,800 & \\
\hline Hari ke-10 & 1388,800 & 123,008 & 91,142 & \\
\hline Hari ke-15 & 1383,200 & 122,512 & 91,142 & 90,700 \\
\hline Hari ke-20 & 1764,000 & 143,080 & 91,888 & \\
\hline Hari ke-25 & 1383,200 & 126,464 & 90,857 & \\
\hline Hari ke-30 & 1568,000 & 166,600 & 89,375 & \\
\hline
\end{tabular}

Tabel 8. Efisiensi sistem zeolit teraktivasi basa dalam menurunkan nilai COD limbah cair industri tahu

\begin{tabular}{|c|c|c|c|c|}
\hline \multirow{2}{*}{$\begin{array}{c}\text { Waktu } \\
\text { sampling }\end{array}$} & \multicolumn{2}{|c|}{ Nilai COD (mg/l) } & \multirow{2}{*}{$\begin{array}{c}\text { Persentase } \\
\text { Penurunan } \\
\quad(\%)\end{array}$} & \multirow[t]{2}{*}{ Efisiensi (\%) } \\
\hline & $\begin{array}{c}\text { Sebelum } \\
\text { diolah }\end{array}$ & $\begin{array}{c}\text { Sesudah } \\
\text { diolah }\end{array}$ & & \\
\hline Hari ke-5 & 1984,000 & 188,480 & 90,500 & \\
\hline Hari ke-10 & 1388,800 & 101,184 & 92,714 & \\
\hline Hari ke-15 & 1383,200 & 104,728 & 92,428 & 91,928 \\
\hline Hari ke-20 & 1764,000 & 123,480 & 93,000 & \\
\hline Hari ke-25 & 1383,200 & 104,728 & 92,428 & \\
\hline Hari ke-30 & 1568,000 & 148,960 & 90,500 & \\
\hline
\end{tabular}

Tabel 9. Efisiensi sistem zeolit terimpregnasi $\mathrm{TiO}_{2}$ dalam menurunkan nilai COD limbah cair industri tahu

\begin{tabular}{|c|c|c|c|c|}
\hline \multirow{2}{*}{$\begin{array}{c}\text { Waktu } \\
\text { sampling }\end{array}$} & \multicolumn{2}{|c|}{ Nilai COD (mg/l) } & \multirow{2}{*}{$\begin{array}{c}\text { Persentase } \\
\text { Penurunan } \\
(\%)\end{array}$} & \multirow[t]{2}{*}{ Efisiensi (\%) } \\
\hline & $\begin{array}{c}\text { Sebelum } \\
\text { diolah }\end{array}$ & $\begin{array}{c}\text { Sesudah } \\
\text { diolah }\end{array}$ & & \\
\hline Hari ke-5 & 1984,000 & 225,150 & 88,802 & \\
\hline Hari ke-10 & 1388,800 & 130,944 & 90,571 & \\
\hline Hari ke-15 & 1383,200 & 128,440 & 90,714 & 89,917 \\
\hline Hari ke-20 & 1764,000 & 172,480 & 90,220 & \\
\hline Hari ke-25 & 1383,200 & 130,416 & 90,571 & \\
\hline Hari ke-30 & 1568,000 & 178,360 & 88,626 & \\
\hline
\end{tabular}

Hasil pengukuran menunjukkan nilai COD yang besar sebelum pengolahan yaitu berkisar antara 1300$2000 \mathrm{mg} \mathrm{L}^{-1}$. Hal ini menunjukkan tingginya zat organik yang terkandung di dalam limbah cair tersebut. Semakin tinggi zat organik yang terkandung di dalam limbah, maka kebutuhan oksigen 
untuk mengoksidasi secara kimia juga besar.

Penurunan nilai COD limbah cair industri tahu pada ketiga sistem menunjukkan nilai yang tidak jauh berbeda. Apabila dilihat ambang batas yang diperbolehkan untuk nilai COD sebesar (275 mg/l), maka hasil pengolahan mempunyai nilai COD (100$226 \mathrm{mg} \mathrm{L}^{-1}$ ) yang telah memenuhi nilai standar baku mutu yang ditetapkan. Efisiensi sistem zeolit dalam menurunkan nilai COD limbah cair industri tahu untuk sistem teraktivasi asam, sistem zeolit teraktivasi basa dan sistem zeolit terimpregnasi $\mathrm{TiO}_{2}$ berturut-turut sebesar 90,70 \%; 91,928 \% dan 89,917\%. Proses ini tidak terlepas dari optimalnya penyerapan oleh zeolit yang ada pada sistem dan optimalnya mikroorganisme yang mendegradasi limbah cair tersebut.

Efisiensi ketiga sistem zeolit dalam menurunkan nilai TSS, BOD dan COD limbah cair industri tahu tidak jauh berbeda. Sistem zeolit teraktivasi basa mempunyai efisiensi yang lebih besar dalam menurunkan nilai TSS, BOD dan COD dibandingkan sistem zeolit teraktivasi asam dan terimpregnasi $\mathrm{TiO}_{2}$. Kondisi ini disebabkan karena zeolit teraktivasi basa mengalami dekationisasi. Dekationisasi atau pertukaran kationkation dalam zeolit menimbulkan gradien elektromagnetik yang terjadi pada kanalkanal dan ruangan-ruangan zeolit (Smith, 1992 dalam Setyawan dan Handoko, 2004). Hal ini juga menyebabkan rendahnya rasio $\mathrm{Si} / \mathrm{Al}$ pada zeolit. Keadaan ini akan mengakibatkan molekul-molekul organik berinteraksi lebih kuat dengan medan elektronik intrakanal dan gradien medan elektronik intrakristal pada zeolit, sehingga sistem zeolit teraktivasi basa dapat lebih maksimal dalam proses penyerapan limbah (Setyawan dan Handoko, 2004). Pada sistem zeolit teraktivasi asam, zeolit mengalami dealuminasi yang disebabkan perendaman atau pencucian menggunakan $\mathrm{HCl}$. Dealuminasi ini akan mengakibatkan kenaikan rasio $\mathrm{Si} / \mathrm{Al}$. Naiknya rasio Si/Al menyebabkan kation-kation yang dapat ditukar dan disubstitusi lebih sedikit. Pada sistem zeolit terimpregnasi $\mathrm{TiO}_{2}$ juga mengalami dealuminasi yang disebabkan oleh uap air pada temperatur kalsinasi yang dapat menghidrolisis alumunium dalam kerangka zeolit. Selain itu uap air pada temperatur kalsinasi juga dapat mengakibatkan ketidakstabilan kerangka oksigen, yang dapat mengakibatkan atom $\mathrm{Si}$ berpindah ke tempat kosong yang ditinggalkan $\mathrm{Al}$, sehingga ukuran selnya akan menyusut. Penyusutan tersebut mengakibatkan meningkatnya rasio $\mathrm{Si} / \mathrm{Al}$ dan mengecilnya ukuran pori (Setyawan dan Handoko, 2004).

\section{KESIMPULAN}

Berdasarkan penelitian yang dilakukan dapat diambil beberapa kesimpulan sebagai berikut :

1. Kecepatan pengisian optimum limbah cair ke dalam ketiga sistem zeolit teraktivasi asam, teraktivasi basa dan sistem zeolit terimpregnasi $\mathrm{TiO}_{2}$ adalah $320 \mathrm{~L} \mathrm{~m}^{-2}$ hari $^{-1}$.

2. Efisiensi penurunan nilai TSS, BOD dan COD limbah cair industri tahu dari sistem zeolit teraktivasi asam adalah 83,348 \%; 91,899 \%; $90,700 \%$, dari sistem zeolit teraktivasi basa adalah 84,380 \%; 93,711\%; 91,928\%, dan dari sistem zeolit terimpregnasi $\mathrm{TiO}_{2}$ adalah $82,415 \% ; 90,711 \% ; 89,917 \%$.

3. Sistem zeolit teraktivasi basa lebih baik dibandingkan dengan sistem zeolit teraktivasi asam dan terimpregnasi $\quad \mathrm{TiO}_{2} \quad$ dalam menurunkan nilai TSS, BOD dan COD limbah cair industri tahu.

\section{UCAPAN TERIMAKASIH}

Terimakasih kami sampaikan kepada Dekan Fakultas Sains dan Teknik Universitas Jenderal Soedirman atas kesempatan yang diberikan kepada 
penulis untuk melakukan penelitian dari sumber dana DIPA Fakultas Sains dan Teknik.

\section{DAFTAR PUSTAKA}

Amun, A. S dan Fahrurozi. 2004.

Kesetimbangan Adsorbsi Optimal Campuran Biner Cd (III) Dengan Zeolit Alam Terimpregnasi 2merkaptobenzotiazol, http.unri.ac.id/jornal/jornal_natur/ Vol6(2)/amun.pdf. Diakses pada tanggal 23 Januari 2007.

Majiburrohman. 2000. Pemanfaatan Tubifex sp Untuk Menurunkan Kandungan Bahan Organik Limbah Cair Tahu Pada Skala Laboratorium. Skripsi. Fakultas Pertanian Universitas Jenderal Soedirman, Purwokerto (Tidak dipublikasikan).

Nurhasan, B., Pramudyanto. 1997. Penanganan Air Limbah Pabrik Tahu. Yayasan Bina Karya Lestari, Jakarta.

Poerwadi, B., B.K. Pariadi, Ariseno. 1998. Pemanfaatan Zeolit Alam Indonesia Sebagai Adsorben Limbah Cair dan Fluidisasi Dalam Kolom Fluidisasi. Majalah Ilmiah UNSOED, Purwokerto.

Purwati. 1997. Penggunaan Koagulan Ferro Sulfat dan Zeolit Termodifikasi Pada Pengolahan Limbah Cair Industri Tekstil. Skripsi. FMIPA-UGM, Yogyakarta (Tidak dipulikasikan).

Santoso, S. Suwarso, A. Irianto, Hernayanti dan N. Andriani. 1996. Potensi Kualitas dan Toksisitas Hasil Pengolahan
Limbah Cair Industri Tapioka Dengan Lapis Tritis (Trickling Filter) Untuk Budidaya Ikan Nila Merah. Laporan Penelitian. Fakultas Biologi UNSOED, Purwokerto. (Tidak dipublikasikan).

Setyawan, D dan P. Handoko. 2004. Pengaruh Perlakuan Asam, Hidrotema, dan impregnasi Pada Zeolit Alam Sebagai Pengemban Kromium Dalam preparasi Katalis. Jurnal Matematika dan Ilmu Pengetahuan Alam Vol 3 no 2. Universitas Jember. Seri Sains Juli 2002, 103-109.

Sugiyanto, R. 2006. Pengaruh Campuran Zeolit- $\mathrm{TiO}_{2}$ terhadap Amonia, Krom Total dan warna Limbah Cair Industri Tekstil. Skripsi. Program Sarjana MIPA Universitas Jenderal Soedirman, Purwokerto (Tidak dipublikasikan).

Suwarso. 2004. Efektivitas Proses Biodegradasi Limbah Cair Industri Tapioka Menggunakan Rekayasa Mikrobiologi. Majalah Ilmiah UNSOED, 11(1), 61-72.

Widodo. 2005. Pengaruh Campuran Dolomit dan $\mathrm{TiO}_{2}$ terhadap BOD, COD dan TSS Limbah Cair Industri Tekstil. Skripsi. Universitas Jenderal Soedirman, Purwokerto (Tidak dipublikasikan). 